\title{
Health hazards and the socioeconomic status of female labour of tobacco processing mills in Kushtia, Bangladesh
}

\author{
Fahmida Khatun, M. Kamruzzaman, Mominul Islam, Shofikul Islam, Hafizur Rahman, Rezaul \\ Karim*
}

Department of Applied Nutrition and Food Technology, Islamic University, Kushtia-7003, Bangladesh

\author{
Email address: \\ mrkarimbio@yahoo.com (R. Karim)
}

To cite this article:

Fahmida Khatun, M. Kamruzzaman, Mominul Islam, Shofikul Islam, Hafizur Rahman, Rezaul Karim. Health Hazards and the Socioeconomic Status of Female Labour of Tobacco Processing Mills in Kushtia, Bangladesh, Science Journal of Public Health. Vol. 1, No. 1, 2013, pp. 1-8 doi: 10.11648/j.sjph.20130101.11

\begin{abstract}
This cross sectional study was conducted to identify prevalence of different disease symptoms, nutritional and socioeconomic status in women workers working in tobacco processing plants. The survey was done on a sample of 240 (Two hundred and forty) female tobacco workers. The study was done by direct participatory observation method. The target persons were interviewed on the basis of prepared questionnaires to trace out the research findings. They were physically observed and their anthropometric measurement was done as well as blood pressure and pulse reading was also taken. The study showed a significant prevalence of respiratory ailment, acute physical weakness and biting pain in limbs. Besides, wheezing, shortness of breath with wheezing, chest pain, cardiac palpitation, lethargy, eye irritation and redness, low blood pressure, underweight, nausea, skin irritation, loss of appetite, insomnia or oversleep, diarrhea and constipation were also found to a considerable percentage. Respiratory symptoms were recorded in $61 \%$ female tobacco workers. $90 \%$ were suffering from acute physical weakness and $65 \%$ from biting pain in limbs particularly in hands and legs. The study showed poor nutritional and socioeconomic status of female tobacco workers. Over half (55\%) of them were underweight while $45 \%$ were of normal weight. Among the underweight category $40 \%, 10 \%$ and $5 \%$ were respectively mild, moderate and severely underweight. Due to poverty they were malnourished along with poor working and living environments makes them more prone to be suffered from repeated attack of communicable and non-communicable diseases.
\end{abstract}

Keywords: Tobacco, Health Hazards, Socioeconomic, Respiratory Symptoms, Physical Weakness, Female worker

\section{Introduction}

Tobacco (Nicotiana tabacum) is a plant and its nonedible leaf is dried to produce cigarettes, pipe tobacco, cigars, chewing tobacco and snuff. It is universally known that tobacco use brings health hazard [1]. Tobacco use contributes to chronic diseases and health problems including cancers, cardiovascular diseases, strokes, tuberculosis, respiratory diseases, gastrointestinal disorders, problems of the oral cavity, reduced physical fitness, increased risk of osteoporosis and broken bones, cataracts, blindness, and increased time needed to recover from illness [2,3]. Cigarette smoking and tobacco uses also lead to the alteration of the lipoprotein levels [4]. Gaur, Kasliwal and Gupta (2012), on a retrospective study, reported a strong association between ear diseases and tobacco uses [5]. 1.3 billion people of the 6.6 billon people of the earth are smoker and by 2030, expected single biggest cause of death worldwide would be tobacco uses, which will be more than the deaths from HIV, malaria, tuberculosis, maternal mortality, automobile crashes, homicides and suicides combined [6,7]. Furthermore, in developing country by 2025 , tobacco related diseases are expected to account for $11 \%$ of all death $[8,9]$. Some studies also documented that smoker and tobacco user are more susceptible to chronic infectious disease than non-smoker [10].

Like cigarette smoking and other forms of tobacco use, working in tobacco industry also leads to the uptake of many hazardous compounds and their metabolites. These hazardous substances may react with biological molecules, and leads to the formation of reactive oxygen species (ROS) and give rise to oxidative stress [11]. Though the prevalence of tobacco use are more among men than women, 
workers in tobacco industry are mostly female [12]. According to the study conducted by Bangladesh Institute of Labor more than millions of workers are engaged in tobacco industries and most of them were women and children [13]. Along with continuous inhalation of tobacco dust, unhygienic and overcrowding working and living environment without basic services and utilities makes them more vulnerable to suffer from various chronic and infectious diseases [14,15].

Association between tobacco use and several noncommunicable diseases not only the social problems for developing countries but physiological complications among tobacco workers are also the major problems indeed. Physical disorders among tobacco workers have been reported by several authors $[13,16,43]$, although there were few studies particularly on female workers. In Bangladesh most of the tobacco workers are female. Kushtia is one of the most important tobaccos growing and processing zone in Bangladesh and almost $95 \%$ of workers are women. From this point of view the present investigation has been undertaken in several tobacco processing plants, those grades and process tobacco leaves, in order to study the prevalence of different physiological abnormalities of tobacco workers who were occupationally exposed to tobacco dust in their work place.

\section{Materials and Methods}

\subsection{Study Design}

This cross-sectional study was carried out on workers of different tobacco processing factories located in different area of Kushtia district, which is located at the southwest region of Bangladesh. Kushtia is the most important tobacco growing and processing zone next to Rangpur district in Bangladesh. In kushtia most of the tobacco processing factories are located at Jugia and Mongolbaria villages in Barokhada Union Parishad under the Sadar Upazilla of Kushtia district. The study was conducted for two month starting from 1st May and ended on 31st June 2008. This two month is considered the peak season of tobacco processing. Almost $95 \%$ of workers in tobacco processing mills are female and the remaining 5\% are male. Tobacco processing mills were selected randomly and the survey was conducted on 240 female tobacco workers who do not take tobacco in any form basically. The purposes of this study and study protocol were first described to the responded and their consent to participate in the study was taken. A structured questionnaire was used to collect details data. Age, educational qualification, marital status, total working period, annual working duration and the presence or absence of studied health complications e.g. chest pain, shortness of breath, weakness etc., and anthropometric measurement of the respondents were included in the questionnaire. Their nutritional and socioeconomic status was also collected. Working environment of the tobacco processing factories and the physical condition of the res- pondent was also observed.

\subsection{BMI and Blood Pressure Measurement}

For measuring blood pressure in this study, we used standard protocol recommended by the World Health Organization. Both systolic and diastolic blood pressures (SBP and DBP) were measured three times with a mercury sphygmomanometer with subjects sitting after 20 minutes rest. The average of three measurements was used for analysis. We also categorized the low, normal and high blood pressure according to the WHO recommendation. BMI (body mass index) was calculated as body weight $(\mathrm{Kg})$ divided by height square $\left(\mathrm{m}^{2}\right)$.

\subsection{Data Analysis}

The total responded were categories according to their age group, marital status and educational qualification. They were also categories according to their working (total and annual) habit and to their BMI. According to the presence or absence of different sign and symptoms, prevalence of health complications was analyzed both in number and percentage.

\section{Results}

In this study, the mean age of the workers was found 38 \pm 2.56 years. On an average each of them has been working for $9.05 \pm 6.55$ years. Table 1 shows the age groups $26-35$ of female tobacco workers belongs to the largest portion (35\%) while the age group of 36-45 has the second largest portions of members $(30 \%)$ following others age groups. The least portions $(5 \%)$ were old ladies in the age group of 56-65, those who works to earn their own bread. Most of the female workers $(65 \%)$ were in the age group of 26 to 45 years. The largest portion of studied workers was widows consisting almost $43 \%$. Among others $30 \%$ was married but their husbands do not feed them and $25 \%$ were married and stay with their husbands and only $2.5 \%$ are unmarried.

From the Table 1 it has been shown that most of the women were working in the tobacco industries for one to over 20 years. Almost 32\% women were working for over 10 years, $23 \%$ for over 20 years and $22.5 \%$ for over five years. Almost $85 \%$ of the workers were illiterate, only $10 \%$ do know how to read and 5\% got their primary school education. Most workers (72\%) work for seasonal, as tobacco leaf processing is chiefly a seasonal business. However $28 \%$ worker works all the year round.

The Table 1 also shows the picture of the poor nutritional status of female tobacco workers. None of them were overweight or obese. Over half $(55 \%)$ of them were underweight while $45 \%$ were of normal weight. Among the underweight category $40 \%$ were in Grade I while 10\%, 5\% of studied workers were moderately and severely malnourished respectively. Their substandard nutritional status was due to poverty and unhygienic working and living envi- 
ronment. Repeated attacks of different types of infectious disease also always keep them under unstable physical condition. Many of them lose their appetite; suffer from metabolic disorder and their weight goes towards a downward trend.

Table 1. Demographic characteristics of the study subjects.

\begin{tabular}{|c|c|c|}
\hline \multicolumn{2}{|l|}{ Characteristics } & \multirow{2}{*}{$\begin{array}{l}\text { Number of Workers (\%) } \\
36(15)\end{array}$} \\
\hline Age Group & $16-25$ & \\
\hline & $26-35$ & $84(35)$ \\
\hline & $36-45$ & $72(30)$ \\
\hline & $46-55$ & $36(15)$ \\
\hline & $56-65$ & $12(5)$ \\
\hline \multirow[t]{4}{*}{ Marital Status } & Married (staying with husband) & $60(25)$ \\
\hline & Married (left but not divorced by husband) & $72(30)$ \\
\hline & Widow & $102(42.5)$ \\
\hline & Single & $06(2.5)$ \\
\hline \multirow{5}{*}{$\begin{array}{l}\text { Total } \\
\text { Working Period }\end{array}$} & Less than 1 year & $24(10)$ \\
\hline & Over 1 year & $30(12.5)$ \\
\hline & Over 5 year & $54(22.5)$ \\
\hline & Over 10 year & $76(31.66)$ \\
\hline & Over 20 year & $56(23.33)$ \\
\hline \multirow{2}{*}{$\begin{array}{l}\text { Annual Work } \\
\text { Duration }\end{array}$} & Whole Year & $68(28.33)$ \\
\hline & Six Month & $172(71.6)$ \\
\hline \multirow{3}{*}{$\begin{array}{l}\text { Educational } \\
\text { Qualification }\end{array}$} & Illiterate & $204(85)$ \\
\hline & Basic Literacy & $24(10)$ \\
\hline & Completed primary Education & $12(5)$ \\
\hline \multirow{7}{*}{$\begin{array}{l}\text { Category } \\
\text { According to BMI }\end{array}$} & Overweight (25.0 - 29.9) & $00(0)$ \\
\hline & Obese $(\geq 30)$ & $00(0)$ \\
\hline & Normal $\quad(18.5-24.9)$ & $108(45)$ \\
\hline & Underweight $(<18.5)$ & $132(55)$ \\
\hline & Mild Underweight (Grade I) (17.0-18.49) & $96(40)$ \\
\hline & Moderate Underweight (Grade II) $(16.0-16.99)$ & $24(10)$ \\
\hline & Severe Underweight (Grade III) $(<16)$ & $12(5)$ \\
\hline
\end{tabular}

Distributions of the subclinical symptoms among the study are shown in Table 2. 50\% workers were affected by heart palpitation while $75 \%$ from low blood pressure. Most of the workers $(91.66 \%)$ were suffered from eye burning whereas $50 \%$ from eye irritation and $75 \%$ and $17 \%$ from blurred vision and poor vision respectively. As the working years increase these two symptoms aggravate. Among other clinical symptoms nausea was prevalent among $70 \%$ of studied workers and vomiting, loss of appetite, diarrhea and constipation were among $10 \%, 60 \%, 5 \%$ and $40 \%$ respectively. Among workers $66.66 \%$ and $52.5 \%$ had skin irritation and skin dryness and only $1.6 \%$ had eczema. 95\% 
workers were suffering from sleeping disorders, whereas $50 \%$ from insomnia and $45 \%$ from oversleeping as well. Only 5\% workers had normal sleep. $65 \%$ workers were feeling biting pain in limbs.

Table 2. Distribution of Subclinical Symptoms in the study subjects.

\begin{tabular}{|c|c|c|}
\hline \multicolumn{2}{|c|}{ Distribution criteria } & \multirow{2}{*}{$\begin{array}{l}\begin{array}{l}\text { Number of } \\
\text { Workers Affected (\%) }\end{array} \\
60(50)\end{array}$} \\
\hline \multirow{3}{*}{$\begin{array}{l}\text { Cardiac } \\
\text { Symptoms }\end{array}$} & Heart Palpitation & \\
\hline & Low Blood Pressure & $90(75)$ \\
\hline & Irritation & $120(50)$ \\
\hline & Burning & $220(91.66)$ \\
\hline \multicolumn{3}{|l|}{ Eye Ailment } \\
\hline & Blurred Vision & $180(75)$ \\
\hline & Poor Vision & $40(17)$ \\
\hline & Irritation & $160(66.66)$ \\
\hline \multirow[t]{3}{*}{ Skin Problen } & Eczema & $4(1.6)$ \\
\hline & Dryness & $126(52.5)$ \\
\hline & Insomnia & $120(50)$ \\
\hline \multirow[t]{4}{*}{$\begin{array}{l}\text { Sleeping } \\
\text { Fluctuation }\end{array}$} & Over sleep & $108(45)$ \\
\hline & Normal & $12(5)$ \\
\hline & Nausea & $168(70)$ \\
\hline & Vomiting & $24(10)$ \\
\hline \multirow{4}{*}{$\begin{array}{l}\text { Others } \\
\text { Subclinical } \\
\text { Problems }\end{array}$} & Loss of Appetite & $144(60)$ \\
\hline & Diarrhea & $12(5)$ \\
\hline & Constipation & $96(40)$ \\
\hline & Biting pain in limbs & $156(65)$ \\
\hline
\end{tabular}

Blood pressure reading of female workers according to their working habits is shown in Table 3. Only $21 \%$ had normal blood pressure while $75 \%$ were with low blood pressure and only $4 \%$ with high blood pressure. Workers working for seasonal and working around the whole years were the main victims of low blood pressure. Over $90 \%$ of the workers who were working for over 10 years and 20 years were the worst sufferers. $75 \%$ of those workers work- ing for over 5 years were also suffering from low blood pressure. Moreover, workers working all the year round were the worst sufferers of low blood pressure $(88.23 \%)$ while $70 \%$ of the seasonal workers were suffering from the same.

Table 3. Distribution of the sign of the category of blood pressure by total working period and annual work duration.

\begin{tabular}{|c|c|c|c|c|}
\hline \multicolumn{2}{|l|}{ Variables } & \multicolumn{3}{|c|}{ Blood Pressure (\%) } \\
\hline $\begin{array}{l}\text { Total Working } \\
\text { Period }\end{array}$ & $\begin{array}{l}\begin{array}{l}\text { Number } \\
\text { of workers } \\
\text { (\%) }\end{array} \\
\end{array}$ & $\begin{array}{l}\text { Low BP } \\
\text { n (\%) }\end{array}$ & $\begin{array}{l}\text { High BP } \\
\mathrm{n}(\%)\end{array}$ & $\begin{array}{l}\text { Normal BP } \\
\mathrm{n}(\%)\end{array}$ \\
\hline Less than 1year & $24(10)$ & $6(25)$ & $8(33.33)$ & $10(41.66)$ \\
\hline Over 1 year & $30(12.5)$ & $10(33.33)$ & $2(6.66)$ & $18(60)$ \\
\hline Over 5 year & $54(22.5)$ & $40(74.07)$ & $0(00)$ & $14(25.97)$ \\
\hline Over 10 year & $76(31.66)$ & $70(92.10)$ & $0(00)$ & $6(7.9)$ \\
\hline Over 20 year & $56(23.33)$ & $54(96.42)$ & $0(00)$ & $2(3.6)$ \\
\hline Total & $240(100)$ & $180(75)$ & $10(4.16)$ & $50(20.83)$ \\
\hline \multicolumn{5}{|l|}{$\begin{array}{l}\text { Annual Work } \\
\text { Duration }\end{array}$} \\
\hline $\begin{array}{l}\text { Whole Year } \\
\text { Workers }\end{array}$ & $68(28.3)$ & $60(88.23)$ & $00(00)$ & $8(11.76)$ \\
\hline Seasonal Workers & $172(71.7)$ & $120(69.76)$ & $10(5.81)$ & $42(24.41)$ \\
\hline Total & $240(100)$ & $180(75)$ & $10(4.16)$ & $50(20.83)$ \\
\hline
\end{tabular}

Sign of the respiratory ailments according to their working habits are shown in Table $4.70 \%$ of workers were suffering from chest pain, whereas $50 \%$ and $55 \%$ from shortness of breath and throat dryness respectively. Workers those who works all around the years were the worst sufferer of chest pain and shortness of breath $(91 \%$ and $94 \%$ respectively). $89 \%$ of workers working over 10 years were suffering from chest pain. Among workers working for over 20 years $85.71 \%$ were suffering from chest pain, whereas those who working for over 1 and less than 1 year were in the least. $71.42 \%$ and $68.42 \%$ women workers those who working for over 20 years and 10 years respectively were suffering from shortness of breath. The ratio was $40.74 \%$ for workers those working over 5 years and $20 \%$ for those working for over 1 year or less than one year. However among the yearlong workers, 94.11\% were suffering from this symptom while $32.55 \%$ of the sixmonth workers were suffering from this. Symptom of throat dryness prevail more at the initial stage of work. Throat dryness was prevalent among 83.33\%, 80\% and $77.77 \%$ workers working for less than and above 1 year and for over 5 years respectively. However the percentage of workers with throat dryness was lowered among workers working for longer period and one of the reasons of this 
lowered percentage might be due to gradual adaptation. Seasonal workers suffer more from this symptom. Preva- lence of throat dryness was high among seasonal workers $(65.11 \%)$ than those who work for year round $(35.29 \%)$.

Table 4. Distribution of Respiratory Symptoms by total working period and annual work duration.

\begin{tabular}{lllll}
\hline Variables & \multicolumn{3}{l}{ Respiratory Symptoms } \\
\hline Total Working Period & Number of workers $(\%)$ & $\begin{array}{l}\text { Chest Pain } \\
\mathrm{n}(\%)\end{array}$ & $\begin{array}{l}\text { Shortness of Breath } \\
\mathrm{n}(\%)\end{array}$ & $\begin{array}{l}\text { Throat Dryness } \\
\mathrm{n}(\%)\end{array}$ \\
\hline Less than 1year & $24(10)$ & $4(16.66)$ & $0(0)$ & $20(83.33)$ \\
Over 1 year & $30(12.5)$ & $10(33.33)$ & $6(20)$ & $24(80)$ \\
Over 5 year & $54(22.5)$ & $38(70.37)$ & $22(40.74)$ & $42(77.77)$ \\
Over 10 year & $76(31.66)$ & $68(89.47)$ & $52(68.42)$ & $28(36.84)$ \\
Over 20 year & $56(23.33)$ & $48(85.71)$ & $40(71.42)$ & $18(32.14)$ \\
Total & $240(100)$ & $168(70)$ & $120(50)$ & $132(55)$ \\
\hline Annual Work Duration & & $62(91.17)$ & $64(94.11)$ & $24(35.29)$ \\
Whole Year Workers & $68(28.3)$ & $106(61.62)$ & $56(32.55)$ & $112(65.11)$ \\
Seasonal Workers & $172(71.7)$ & $168(70)$ & $120(50)$ & $132(55)$ \\
Total & $240(100)$ & & & \\
\hline
\end{tabular}

It has been shown from Table 5 that female tobacco workers were suffering from different symptoms of physical weakness. $90 \%$ of them were suffering from general weakness, $85 \%$ from dizziness and $40 \%$ from headache. The prevalence was increasing with increasing the total working period. $96.42 \%$ of the workers working for over 20 years were suffering from general weakness. $100 \%$ of workers working around the year were suffering from weakness whereas $86.04 \%$ of seasonal workers were with this symptom. $94.11 \%$ of year round workers were feeling dizziness whereas $81.39 \%$ of seasonal workers were feel- ing the same. $40 \%$ of total workers were suffering from headache and $40 \%$ of workers those who workings for over 1 year were also suffering from headache. However the prevalence of headache was slightly increased among those who work for more than 5, 10 and 20 years. At the initial stage of working headache were less prevalent whereas those working for long period the prevalence of headache were high. $88.23 \%$ of year round workers were suffering from headache, while only $20.93 \%$ of seasonal workers were suffering from this.

Table 5. Distribution of Sign of Physical Weakness by total working period and annual work duration.

\begin{tabular}{|c|c|c|c|c|}
\hline \multicolumn{2}{|l|}{ Variables } & \multicolumn{3}{|c|}{ Physical Weakness } \\
\hline Total Working Period & Number of workers (\%) & $\begin{array}{l}\text { Weakness } \\
\mathrm{n}(\%)\end{array}$ & $\begin{array}{l}\text { Dizziness } \\
\mathrm{n}(\%)\end{array}$ & $\begin{array}{l}\text { Headache } \\
\mathrm{n}(\%)\end{array}$ \\
\hline Less than 1year & $24(10)$ & $20(83.33)$ & $18(75)$ & $4(16.66)$ \\
\hline Over 1 year & $30(12.5)$ & $24(80)$ & $26(86.66)$ & $12(40)$ \\
\hline Over 5 year & $54(22.5)$ & $48(88.88)$ & $56(85.18)$ & $22(40.74)$ \\
\hline Over 10 year & $76(31.66)$ & $70(92.10)$ & $68(89.47)$ & $34(44.73)$ \\
\hline Over 20 year & $56(23.33)$ & $54(96.42)$ & $46(82.14)$ & $24(42.85)$ \\
\hline Total & $240(100)$ & $216(90)$ & $204(85)$ & $96(40)$ \\
\hline \multicolumn{5}{|l|}{ Annual Work Duration } \\
\hline Whole Year Workers & $68(28.3)$ & $68(100)$ & $64(94.11)$ & $60(88.23)$ \\
\hline Seasonal Workers & $172(71.7)$ & $148(86.04)$ & $140(81.39)$ & $36(20.93)$ \\
\hline Total & $240(100)$ & $216(90)$ & 204 (85) & $96(40)$ \\
\hline
\end{tabular}




\section{Discussion}

In the current study health complication among workers were studied and different of symptoms of health complications were found. No workers were found to use protective masks. The workers were looked tired and weak. Most of them were lean and thin. They were found to work sitting on ground and keeping tobacco leaves very close to their body. In the social perspective of Bangladesh those women were supposed to be engaged in taking care of the family run by their husbands. But, in deviation of the social customs they come to do job for earning money. The alter result of their marital status have shown that most of these women have either been abandoned but not divorced by their husbands or widows. They all come to the job for only of reason of poverty. The widows and abandoned wives have to earn their own livelihood by doing such hazardous job. On the other hand, married women staying with husbands were to earn to assist their husbands. In some cases husbands force them to earn money. Single women were found to scarcely come to do this job and those who came were victim of acute poverty.

Due to illiteracy they have less confidence as well as scope to work anywhere. Once they enter do not want to leave due to better payment and once they get the opportunity to earn from this sector, though hazardous, they do not usually want to switch over. Unawareness of diseases comes naturally with illiteracy. A cross sectional survey on a sample of 223 male and female workers at a cigar and cigarette factory in Lucca (Tuscany) showed a significantly higher prevalence of wheezing, attacks of shortness of breath with wheezing, dyspnea, and rhinitis than in a reference population [17]. A number of study also reported respiratory symptoms among tobacco workers $[18,19]$. Those study reported symptoms of cough, phlegm, dyspnea, feel tightness, nose irritation pulmonary fibrosis among workers of tobacco industry.

Since the beginning of the 18th century, association between inspirable raw tobacco dust with chronic bronchitis and different diseases in tobacco workers are reporting [2027]. Concentration of inspirable dust was found 150 -fold higher in the environment of tobacco factory than in the control environment. Raw tobacco dust can contain bacteria, endotoxins, and fungal spores (moulds), pollen, mites, insects, particulate of inorganic materials such as quartz, and residues of pesticides or insecticides [28-32]. These microorganisms and their metabolites, are also found in damp workplaces, were known to cause symptoms of irritation, hypersensitivity reactions, or allergic diseases [33]. The health condition of tobacco workers were associated with their workplace, and in particular with the illventilated and damp conditions, and with the dust resulting from the grinding of tobacco leaves in the mill. The complaints were included headache, cough, nausea, and vomiting [20]. Valic, Beritic and Butkovic found a significantly increased prevalence of asthma symptoms in tobacco workers compared to that in control subjects [21]. Gleich, Welsh, Yunginger, Hyatt and Catlett described allergy to tobacco as an occupational hazard and suggested that allergic reactions to tobacco antigens in tobacco leaves might be responsible for this disease [22]. Lander and Gravesen, showed that $69 \%$ of tobacco workers reported symptoms of occupational asthma and chronic bronchitis in a tobacco processing plant [23]. Similarly, Kjaergaard et al. reported a significant decrease of $\mathrm{FEV}_{1}$ (Forced Expiratory Volume 1) and FVC (Forced vital capacity) values in tobacco workers compared to referents [24,34-36]. Temporary disability, due to work, caused by upper respiratory tract disease was reported in $36.8 \%$ of workers in the tobacco industry by Sekerova [25].

At the initial stage the workers become weak due to metabolic disorder like vomiting, nausea, loss of appetite and other ailments. They become gradually adopted with the initial symptoms but gain new symptoms like respiratory symptoms, low blood pressure, muscular cramping etc and they become weaker. Weakness is associated with low blood pressure and underweight. A study of 75 workers employed in a tobacco factory producing cheroots measured cellular contents of tear fluid, redness of eyes, discomfort, total and respirable dust in the breathing zone and total ambient dust by stationary sampling. A dosedependent difference in photographically measured eye redness was found among the tobacco workers [37]. Irritation of lips and upper airways as reported by questionnaire were more common in tobacco workers than in referents. A study by S. Mittal, A. Mittal and Rengappa, also reported ocular manifestation among Bidi industry workers [38]. The tobacco workers, more often than the referents, had complaints and objective changes in the mucous membranes of the eyes. These may be related to tobacco dust exposure. Prakash and Vyas studied about tobacco exposure and health hazards in women Bidi industry workers in Ajmer India and found a positive association [39]. Our study represented that the prevalence of respiratory symptoms were higher among those working for longer period of time than those working for shorter period of time. Sneezing and cough were experienced by workers at the initial stage when a worker starts new and they are adopted gradually with the environment. Chest pain, shortness of breath and throat dryness prevails all over their profession. A high prevalence of respiratory symptoms was also found by a study on occupational tobacco exposure [18]. Barry studied on the influence of the U.S. tobacco industry on the health, economy, and environment and indicated the organic dusts in the work places as a synergistic carcinogen for workers [40].

A number of researchers observed the adverse effects of environmental pollution on health of the workers and reported that abnormal working environment and exposure to noxious chemical agents may create specific diseases which abnormally effect on the health status of workers 
$[41,42,43]$. Nausea and vomiting occurs at the starting period of the respondent job. Loss of appetite continues while diarrhea and constipation occurs at times. Constipation may have a link with physical dryness. Because of poverty they are not properly nourished as well. But due to metabolic disorder they cannot take and absorb what they have. Irritation of skin in the female workers occurs over dust on exposed portions of the body. Long term exposure to tobacco dust cause acute irritation and ultimately turn into Eczema. Dryness is very common among workers. It may be an outcome of gradual nutritional decay caused by nutrient shortage coming out of their low income. Green tobacco sickness (GTS) occurs in workers working with the green tobacco plant and is a potential health risk to those. It's mainly caused by handling green and fresh wet leaves of tobacco. The symptoms of tobacco workers that are reported in the current study are also reported by several studies among green tobacco workers $[44,45,46]$.

The female workers were usually found to start their work at the time when a woman in the society usually runs her family with children with financial support from their husband. But most of the workers were forced to join such hazardous job against social customs for women only due to poverty. However, they earn very little. Their everyday income was only Taka 60 , which was not sufficiently enough to bear the cost of their daily food commodities. As a result they were being pushed towards a fatal nutritional problem and various malnutrition related diseases develop.

\section{Conclusions}

Kushtia is one of the most important tobacco processing zones in Bangladesh and most of the workers in the tobacco industries are female. The aim of this study was to assess the prevalence rate of health associated complication among tobacco workers. Female workers usually do not smoke, but during working they inhale tobacco actively or passively. Tobacco dust also penetrates through their skin and creates skin related complication. This study showed that most of the workers suffer from general weakness and several forms of health complication, but they were little aware about the danger of working in such hazardous tobacco processing industry.

\section{Acknowledgements}

The authors are thankful to the Dept. of Applied Nutrition and Food Technology and to the participant subject for their oral consent to participate in this study.

\section{References}

[1] O. Shafey, M. Eriksen, H, Ross and J. Mackay, "The Tobacco Atlas," 3rd edition. Atlanta: American Cancer Society, 2009.
[2] K. Slama, "Tobacco control and prevention. A guide for low income countries," Paris: International Union against Tuberculosis and. Lung Disease. URL at http://www.iuatld.org/

[3] Smoking attributable mortality and years of potential life lost - United States, 1984, MMWR, 1997, 46 (20): 444-51.

[4] C. Brischetto, W. Connor, S. Connor and J. Matarazzo, "Plasma lipid and lipoprotein profiles of cigarette smokers from randomly selected families: enhancement of hyperlipidemia and depression of high-density lipoprotein," Am J Cardiol, 1983, 52: 675-680.

[5] K. Gaur, N. Kasliwal and R. Gupta, "Association of smoking or tobacco use with ear diseases among men: a retrospective study," Tobacco Induced Diseases, 2012, 10:4.

[6] M. J. Thun and V. L. da. Costa e Silva, "Introduction and overview of global tobacco surveillance. Tobacco Control Country Profiles." 2nd edition. Atlanta, GA: American Cancer Society, 2003, 7-12.

[7] J. Crofton and D. Simpson, "Tobacco, A Global Threat (2002)/World Bank 1999: Curbing the Epidemic," Government and the Economics of Tobacco Control.

[8] World Health Organization: A global status report on Health. (1997), [http:// www.who.int/whr/1997/en/whr97_en.pdf].

[9] World Health Organization: A global status report on alcohol. (2004), [http:// www.who.int/substance_abuse/publications/global_st atus_report_2004_overview.pdf].

[10] J. Bagaitkar, D. R. Demuth and D. A. Scott, "Tobacco use increases susceptibility to bacterial infection," Tobacco Induced Diseases, 2008, 4:12 doi:10.1186/1617-9625-4-12

[11] J. Loeper, J. Goy, L. Rozensztajn, O. Bedu and P. Moisson, "Lipid peroxidation and protective enzymes during myocardial infarction," Clin Chim Acta, 1991, 196:119-125.

[12] M. Rani, S. Bonu, P. Jha, S. Nguyen, L. Jamjoum, "Tobacco use in India: prevalence and predictors of smoking and chewing in a national cross sectional household survey,". Tob Control, 2003:12:e4 doi:10.1136/tc.12.4.e4

[13] M. M. Rahmanm, "Health hazards and quality of life of the workers in tobacco industries: study from three selected tobacco industries at Gangachara thana in Rangpur district of Bangladesh," The Internet Journal of Epidemiology, 2009, 6 (2), DOI: $10.5580 / 14 \mathrm{e} 5$.

[14] M. Ahmed, "Tobacco and economy in Bangladesh, keynote speech delivered on the occasion of world tobacco day, organized by Bangladesh cancer Society, May 31, 1995, Dhaka.

[15] G. K. Rath and K. Chaudhary, "Cost of Tobacco Related Diseases," Paper presented at the WHO International Conference on Global Tobacco Control Law: Towards a WHO Framework Convention on Tobacco Control, January 2000, New Delhi India.

[16] S. N. Kumar, and S. P. Bharathi, "A study on occupational health hazards among women Beedi rollers in Tamilnadu, India," Inernational Journal of Current Research, 2010, 11: 117-122. 
[17] G. Viegi, P. L. Paggiaro, E. Begliomini, E. Vaghetti, P. Paoletti, and C. Giuntini, "Respiratory effects of occupational exposure to tobacco dust" $\mathrm{Br} \mathrm{J}$ Ind Med, 1986, 43(12): 802-808.

[18] J. Uitti, H. Nordman, M. S. Huuskonen, P. Roto, K. Husman and M. Reiman, "Respiratory health of cigar factory workers," Occup Environ Med, 1998, 55:834-839.

[19] M. Ghasemkhani, K. Masaharu, M. Rezaei, A. R. Anvari, A. Mazloumi and H. R. Sadeghipour, "Prevalence of Respiratory Symptoms among Workers in Industries of South Tehran, Iran," Industrial Health, 2006, 44: 218-224.

[20] W. E. McCormick, M. Smith, S.P. Marsh, "A study of the health hazards of the tobacco stemming and redrying industry,” J Industr Hyg Toxicol, 1948, 30(1): 43-52.

[21] F. Valic, D. Beritic abd D. Butkovic, "Respiratory response to tobacco dust exposure," Am Rev Respir Dis, 1976, $113(6) ; 751-755$.

[22] G. J. Gleich, P.W. Welsh, J. W. Yunginger, R.E. Hyatt and J.B. Catlett, "Allergy to tobacco: an occupational hazard," N Engl J Med, 1980, 302(11): 617-619, DOI:10.1056/NEJM198003133021107.

[23] F. Lander and S. Gravesen, "Respiratory disorders among tobacco workers," Br J Ind Med, 1988, 45(7): 500-502.

[24] S. K. Kjaergaard, O. F. Pedersen, M. Frydenberg, H. Schønheyder, P. Andersen and G.. J. Bonde, "Respiratory disease and lung function in a tobacco industry," Arch Environ Health, 1989; 44(3): 164-170.

[25] N. Sekerova, "Temporary disability to work caused by diseases of the upper respiratory tract in the tobacco industry of Plovdiv," Folia Med (Plovdiv), 1969, 11(1): 46-54.

[26] R. A. Bhisey, A. N. Bagwe, M. B. Mahimkar and S. C. Buch, "Carcinogenesis Division, Cancer Research Institute, Mumbai, India. "Biological monitoring of bidi industry workers occupationally exposed to tobacco," Toxicology Letters, 1999, 108 (2-3): 259-265.

[27] M. B. Mahimkar and R. A. Bhisey, "Occupational exposure to bidi tobacco increases chromosomal aberrations in tobacco processors, Mutation Research/Environmental Mutagenesis and Related Subjects, 1995, 334(2): 139-144.

[28] A. Blair, B. W. Berney, M. F. Heid and D. W. White, "Causes of death among workers in the tobacco industry," Arch Environ Health, 1983, 38 (4): 223-8.

[29] J. Dutciewitz, L. Kus, E. Dutkiewicz and C. P. Warren, "Hypersensitivity pneumonitis in grain farmers due to sensitization to Erwinia herbicola, Ann. Allergy, 1985, 54(1): 65-8.

[30] M. Kotimaa, "Occupational exposure to airborne spores of fungi and actinomycetes with special emphasis on agricultural work," Ph.D. dissertation, Kuopio Regional Institute of Occupational Health, Kuopio University, Finland: Antin Paino, 1990.

[31] A. Nevalainen, A. L. Pasanen, M. Niininen, T. Reponen, P. Kalliokoski and M. J. Jantunen, "The indoor air quality in Finnish homes with mold problems," Environ-ment International, 1991, 17(4): 299-302.

[32] D. P. Strachan, B. Flannigan, E. M. McCabe and F. McGar- ry, "Quantification of airborne moulds in the homes of children with and without wheeze, Thorax, 1990, 45: 382-7, doi:10.1136/thx.45.5.382.

[33] T. Husman, "Health effects of indoor-air microorganisms," Scand J Work Environ Health, 1996, 22(1): 5-13.

[34] R. Minelli, "Appunti dalle lezioni di fisiologia umana. La Goliardica Pavese," Pavia, 1992.

[35] M. P. Swanney, G. Ruppel, P. L. Enright, O. F. Pedersen, R. O. Crapo, M. R. Miller, R. L. Jensen, E. Falaschetti, J. P. Schoute, J. L. Hankinson, J. Stocks and P. H. Quanjer, "Using the lower limit of normal for the FEV1/FVC ratio reduces the misclassification of airway obstruction, Thorax, 2008, 63(12): 1046-51. doi:10.1136/thx.2008.098483. PMID 18786983.

[36] H. Sahebjami and P. S. Gartside, "Pulmonary function in obese subjects with a normal FEV1/FVC ratio," Chest, 1996, 110(6): 1425-9. doi:10.1378/chest.110.6.1425. PMID 8989055 .

[37] K. K. Søren and O. F. Pedersen, "Dust exposure, eye redness, eye cytology and mucous membrane irritation in a tobacco industry," Journal International Archives of Occupational and Environmental Health, 1989, 61(8): 519-525.

[38] S. Mittal, A. Mittal and R. Rengappa, "Ocular manifestations in bidi industry workers: Possible consequences of occupational exposure to tobacco dust," Indian J Ophthalmol, 2008, 56(4): 319-322.

[39] B. Prakash and U. Vyas, "Association between occupational tobacco exposures of health hazards in women labors of bidi industry of Ajmer," Int. J. Pharm. Med. \& Bio. Sc, 2013, 2(1): 58-61, ISSN $2278-5221$.

[40] M. Barry, "The influence of the U.S. tobacco industry on the health, economy, and environment of developing countries," New England Journal of Medicine, 1991, 324(13): 917-920.

[41] A. Khaleque and M. S. Elias, "Effects of workplace pollution on health and well-being of workers," In: Human Factors in Organizational Design and Management-III (eds. Noro, K. And Brown, O), Elsevier Science Publisher, Amsterdam, pp. 185-188.

[42] A. Khaleque and M. S. Elias, "Industrial pollution and quality of life of workers in Bangladesh," J. Human Ergology, 1995, 24(1): 13-23.

[43] M. S. Elias and N .K. Saha, "Environmental pollution and health hazard problems of workers in tobacco industries," J. Life Earth Sci., 2009, 3-4: 13-17, ISSN 1990-4827.

[44] J. S. McBride, D. G. Altman, M. Klein and W. White, "Green Tobacco Sickness," Tobacco Control, 1998, 7(3): 294-298.

[45] T. Ballard, M. J. Ehlers, E. Freund, M. Auslander, V. Brandt and W. Halperin "Green Tobacco Sickness: Occupational nicotine poisoning in tobacco workers." Archives of Environmental Health, 1995, 50(5): 384-389.

[46] S. Achalli, S. R. Shetty and S. G. Babu, "The Green Hazards: A Meta-Analysis of Green Tobacco Sickness," International Journal of Occupational Safety and Health, 2012, 2(1) : $11 \quad-\quad 14, \quad$ DOI http://dx.doi.org/10.3126/ijosh.v2i1.4963. 